near the Oxford University Parks, and on the following day I captured eleven more in the same place. There had been exceptionally heavy rain, extending over some days, immediately previous to those on which I found the specimens, and it therefore seems probable that these animals are driven out of the earth when it becomes sodden with moisture. Thus it is possible to account for the capture of a very unusual number of specimens, for, as far as I can learn, the species has hitherto only been met with singly in this locality.

I have also ascertained what happens to the animals when the earth.in which they are contained becomes hard and dry from the loss of water. A few of the twenty-two specimens were killed and hardened, and the remainder were put in a box containing earth, in which they buried themselves. In the press of other work the box was neglected, and remained untouched in my laboratory until to day, the earth having quickly dried into a hard cake. To-day I emptied the box, and fully expected to find the slugs dried up dead, but to my surprise I found twelve specimens alive, each encysted in a thin transparent capsule formed of the hardened mucous secretion of the animal's skin. The body was contracted, and oval in shape, but it had been so conmpletely protected from evaporation that there was no noticeable reduction in bulk after these hottest months of the year, during which water had been entirely withheld. One or two specimens had died almost immediately after capture, and a few escaped, so that all those which had been exposed to the heat and dryness in the box had become encysted, and survived in apparent health.

Wykeham House, Oxford, October 19

\section{Lepidoptera and Migration}

THE subject of migration in connection with Lepidoptera is beginning to receive some attention at the hands of our best lepidopterologists. I am decidedly of opinion that the abundance or scarcity of many species of Lepidoptera is largely regulated by migrations from abroad. Last year our southern shores were visited by an abnormal number of rare Sphingida, but this year there have scarcely been any records of capture; published concerning them. It would be interesting to know what are all the influences which cause these migrations, and if there is a periodicity to the phenomenal occurrences.

Birmingham, October I 2

W. Harcourt Bath

The Earthquake of October 16 in the Vosges, \&c.

MAY I be allowed to call attention to the fact that Alsace lies on the direction of the great circle, "boundary of Tertiary formation of the United States," mentioned in my letter which appeared in your number of the $x 4^{\text {th }}$ inst. (p. 570), and furthermore that Strasburg has been repeatedly shaken since 1355 , the first date which I found recorded as having been marked by a shock. It is quite true that the interval between that shock and the next recorded (1556) was 20 I years ; but the greatest subsequent interval, that between the shocks of 1577 and 1655 , was only of 78 years. This interval represents a multiple of 13 , being $=13 \times 6$. The interval of 13 is of frequent recurrence, as I purpose to show in a paper which I have about terminated on this question of intervals and periods of earthquakes.

J. P. O'REILLy

Royal College of Science for Ireland, Stephen's Green, Dublin, October 23

\section{RECENT ORNITHOLOGICAL WORKS}

THE future student of British birds ought to have little difficulty in working out the distribution of species within the shores of Great Britain, so much excellent work having been done in the way of local lists during the last few years, and certainly one of the most useful will be the little work on "The Birds of Cumberland and Westmoreland," just issued by the Rev. H. A. Macpherson and Mr. W. Duckworth. ${ }^{1}$ The situation of these two counties is interesting, especially to the student of migration, and the notes on the passage of water-birds and sea-birds are particularly good. The completeness of the

I "The Birds of Cumberland critically studied, including some Notes on the Birds of Westmoreland." By the Rev. H. A. Macpherson, M.A., and William Duckworth. (Carlisle, r886) information, and the concise and simple form in which it is conveyed, render this small book a model of what a faunistic work should be, and it forms a worthy accompaniment to the many excellent county lists of birds which have appeared in England during the last twenty years. It would be well if every expiring species in Great Britain had had its death-song as well sung as is the case with the Dotterell, by Mr. F. Nicholson, in the present work. While Protection Acts are spreading their ægis over many birds in the breeding season, so that the numbers are visibly increasing, and the enlightened care of a few landed proprietors aids the work of bird-preservation, there are still a certain number of species whose nesting days in this country are numbered, and which, like the Great Bustard and the Bittern, are doomed by the inexorable advance of civilisation to seek less over-crowded countries in which to breed. The (too probably final) breeding of the Dotterell in Cumberland is therefore appropriately described by Mr. Nicholson, who has himself taken the eggs in the county. An excellent account is likewise given of the breeding of the Pied Flycatchers.

We learn with some surprise that the White-headed Long-tailed Titmouse of Scandinavia, the true Acredula caudata (Linn.), "may be detected in Cumberland in mid-winter," when "the appearance of a flock of adults in their snow-white caps is refreshing to an insular observer." We should like to see some of these Titmice, and may state that an example is a desideratum to the national collection, where we should be glad to receive a specimen. Our experience in France, where we have shot all three races of the Acredula caudata, is that it is impossible to detect the difference of the forms when in the open, though a difference in note led to our recognising $A$. irbii. We can only consider the true $A$. caudata to be a very occasional, though not impossible, migrant to our shores, and we by no means sympathise with the authors of the "Birds of Cumberland" in their suppression of the name of Acredula rosca for the British Long-tailed Titmouse, from a dislike to the "needless multiplication of species." As regards Great Britain the facts are perfectly plain. The resident $A$ credula is always recognisable, and the white-headed form is only a very occasional winter visitant, and however much they may interbreed in the Rhine Provinces or elsewhere on the Continent, there is nothing of the kind in England, where perfect differentiation exists; and therefore to say that our English Long-tailed Titmouse should be called Acredula caudata of Linnæus, is a mistake and nothing else, for that name belongs to the Swedish form. Those ornithologists who continue to do this suppress a most interesting fact in nature, viz. that the isolation of the British Islands from the rest of Europe has produced a well-marked modification in the colour of some of our birds, amounting in certain instances to a subspecific value. The same reasoning applies to the Coal Titmouse, where our authors state that "British specimens have generally olive backs, as contrasted with the slate-gray backs of typical German specimens, but intermediate forms occur." This is not our experience. In summer plumage, when the olive-brown tips and the feathers become shed, the back of the English Coal Titmouse is gray, and then it is difficult to tell it from a summer-plumaged $P$. ater from the Continent. But if two winter-killed birds are compared, the difference between the British and Continental specimens is very strongly marked, for the back in the latter remains gray, whereas in the British form it is olivebrown. Having been the first, as we believe, to detect this modification in the British form, we have, ever since we first gave it the name of Parus britannicus, assiduously collected a series of specimens in the British Museum, and we have never seen reason to modify our original opinion, nor have we yet seen the intermediate forms for which our authors vouch. 